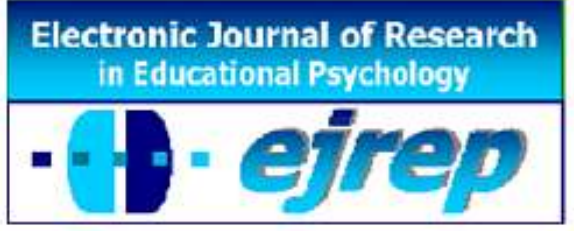

\title{
Relevance of videogames in the learning and development of young children
}

\author{
Zhuxuan Zhao \& José L. Linaza
}

Departamento de Psicología Evolutiva y de la Educación, Universidad Autónoma de Madrid

\section{Spain}

Correspondence: Zhuxuan Zhao. Plaza Verín, 4, 10.4 Madrid 28029. Spain. E-mail: zzx1011@ gmail.com

(C) Education \& Psychology I+D+i and Ilustre Colegio Oficial de la Psicología de Andalucía Oriental (Spain) 


\section{Abstract}

Introduction. The study was carried out with children of $2^{\text {nd }}, 4^{\text {th }}$ and $6^{\text {th }}$ grades of elementary school in order to explore what and how will children learn from a completely new videogame.

Method. We organized children from $2^{\text {nd }}, 4^{\text {th }}$ and $6^{\text {th }}$ grades of elemental school, giving them chance to play a freshly released videogame by that time. We formed small groups of 4 players with 2 boys and 2 girls in each group. We offered them a console and only 2 controllers. With this design, we would like to observe and analyze the differences between these players according to their age and gender. This process of learning and playing videogames lasted for 11 weeks.

Result. The results have shown the capacity of learning without adult's intervention among all the players in this study. It also shows the coordination of cooperation of each group in order to learn to play the video game. We'd like to highlight their autonomy in learning and their ability to solve different conflicts happened during the process in their group, from the beginning and during the play time, their way of regulate each player's play time and also their capacity of create meanings in the game's virtual world, characters or concrete actions.

Discussion. Complex and important capacities were displayed during the learnig process by the children: leadership, caring for other players, control of the process, etc.

Keywords: Video games, Children, Learning, Gender 


\title{
La relevancia de los videojuegos en el aprendizaje y el desarrollo de niños de temprana edad
}

\begin{abstract}
Resumen
Introdución Realizamos el presente estudio, con niños y niñas de $2^{\circ}, 4^{\circ}$ y $6^{\circ}$ de educación primaria para saber cómo y qué pueden aprender los niños mientras se enfrentan con un nuevo videojuego.
\end{abstract}

Método. Organizamos con niños de $2^{\circ}, 4^{\circ}$ y $6^{\circ}$ de primaria la posibilidad de jugar un videojuego recién salido al mercado. Formamos grupos pequeños de 4 jugadores cada uno, 2 niños y 2 niñas, y les ofrecimos una consola y sólo 2 controles para jugar. Con este procedimiento queríamos observar y analizar las diferencias entre jugadores de diferentes edades y las posibles diferencias de género. El proceso de aprendizaje y uso del videojuego se extendió a lo largo de 11 semanas.

Resultado. Los resultados muestran la capacidad de aprendizaje de los jugadores de todas las edades sin instrucción específica de los adultos. También la coordinación y la cooperación en cada uno de los grupos para lograr tal aprendizaje y, con él, poder utilizar el videojuego. Destacan tanto la autonomía en el proceso de aprender, como la capacidad para resolver en el grupo los diferentes tipos de conflictos surgidos a lo largo del juego, en su iniciación o en el curso del aprendizaje y en su regulación, así como la capacidad para crear el significado del mundo virtual del juego, de los personajes o de acciones concretas.

Discusión. La expresión de capacidades muy complejas e importantes (liderazgo, cuidado de otro jugador, control del proceso) en jugadores tan jóvenes.

Palabras Claves: Videojuegos, Aprendizaje, Niños, Género. 


\section{Introduction}

Just a few words to highlight the relevance of play in children`s development according to the great theories of Freud, Piaget and Vygotsky (Bruner, 1972a). In fact Bruner (1972b, 2012; Linaza \& Bruner, 2012) have argued that play, as a consequence of children's immaturity, is a powerful mechanism for human adaptation to a complex and difficult to predict environment.

Videogames are a new and growing phenomenon of play in our technological and post-industrial societies. It seems very important the study and comprehension on these new forms of play and their consequences in human development. The most common concern about videogames nowadays seems to be the violence in game. According to the traditional behaviorist thinking about learning, when children or adults play a videogame, they will inevitably imitate what's inside the videogame then act the same way in real life Ferguson (2010). In short, if you play a military themed videogame like Call of Duty, you will begin to be influenced by it and in the end start shooting people in real life. However Ian Bogost stated in his book Persuasive Games: the expressive power of videogames:

Playing a role in a videogame does not automatically imply validation for the behavior the game models, As I have argued, videogames can also give players the opportunity to empathize with people and situations they might not ordinarily encounter. Videogames teach abstract principles that service general problem-solving skills and learning values. It encourages the learner to experiment within knowledge domains freely without fear of incompetence due to incomplete mastery. (p. 230-231)

Other researchers of videogames have expressed similar opinions about what technique videogames actually teach: "the game teaches players how to convert skills into strategies, and to turn failure into success" (James Paul Gee, "Demonstrating the important Learning Found in COTS Games", 2004) Taking a step back from the immediate situation, analyzing the choices and the odds, and finding the right strategy. (Beck \& Wade, Got Game: How the Gamer Generation Is Reshaping Business Forever, Cambridge, Mass.: Harvard Business School Press, 2004)

Guerrero defends in his article Herramientas lúdicas, pedagógicas y metodológicas a través de los videojuegos that videogames giving its capacity of communicating and submerging individuals into a imaginary world, can be used for creating a way of playing for 
educative entertainment, in this way it can prevent the ambient risks that young people of 14 to 25 years old in Colombia suffer and make their life better. (Guerrero, 2014)

Therefore we have conducted this research on one of these new videogames trying to explore some of the possible differences between boys and girls while playing the game as well as the potential influence of players' age to learn how to play it.

\section{Objectives and hypotheses}

Some of our hypotheses were based on previous studies on games and videogames. For examples: Baveliere (2003). Action video games modifies visual selective attention; McGonigal (2011) wrote: videogames can modify us for the better and change the world; González et al. (2013) has proved the positive influence of video games in hospitalized children; Lacasa, Méndez and Martínez (2009) argue that some videogames improves the process of learning citizenship education; Others were based on commonly held beliefs among the population, including parents and teachers.

a. There is a spontaneous interest to explore and participate in a game, even when nothing is known about its content and characteristics. Boys or girls, from the three age groups, will actively participate in Skylanders.

b. The kids will actively participate in the collaborative creation of game meaning. Each one will explore intensely, with determination and tenacity, the different elements of the game. Each one will also share with the other members everything he or she has discovered. Playing together means cooperating.

c. The kid who knows the most or understands the game at a faster rate will offer that knowledge to those who are slower learners. This scaffolding (completing, supporting and explicitly teaching concrete actions to less competent players) allows the kids to rapidly acquire a standardized skill level and the game becomes more interesting.

d. The conflicts will be resolved faster given the limited time available to play. It is always better to keep on playing rather than interrupt the game session because of a conflict.

e. The boys and girls of 6th grade (11 and 12 years old) will show a great deal of autonomy and will go without any assistance from adults, when exploring and participating in the game as well as when resolving their conflicts. Those in 2nd 
grade will tend to ask more questions to adults as they start playing, when they face a persistent challenge or when a conflict arises between them. The boys and girls of 4th grade ( 9 and 10 years old) are somewhere between the two previous groups regarding the initial instructions as well as during the conflicts.

f. All of them, regardless of their age or gender, will feel pleased to have participated and will openly and explicitly show a great deal of satisfaction.

g. Boys and girls will gladly and actively participate in the game. Nevertheless, and given that there are constant opportunities to play adventures or battles, we expect to see a greater interest from the male participants and less from the girls in the battle modes.

\section{Method}

\section{Participants}

A total of 50 boys and girls of 2nd, 4th and 6th grade of Elementary School have participated with corresponding ages of 7-8, 9-10, and 12-13 respectively. The age and gender distribution in groups was: 16 in 2nd grade ( 8 boys and 8 girls), 16 in 4th grade (also 8 boys and 8 girls) and 18 in 6th grade ( 9 boys and 9 girls). The groups always consisted of boys and girls, in most cases 2 boys and 2 girls. There were always more players ( 3 or 4 ) than controllers and participating players.

\section{Instruments}

We used one game console Xbox360 with two joypad controllers; two flat screen TVs; one video camera for recording the children while they playt the game Skylanders with its accessories (Action figures for the game and portal to introduce these figures into the game).

\section{Procedure}

We have allowed the children to play both game modes: Adventure Mode, which is a cooperative mode of two players progressing through a story, and the Battle Mode, the clash of player against player in three different scenarios: battle arena, goals and finding gems. We have deliberately formed groups of players that always included boys and girls. In one case the game was tested by just two girls because of the unexpected absence of the male player. 
The game play sessions have been extended throughout 11 weeks, in the months of March, April and May of 2012, in the Computer Lab of the "Principe de Asturias" Public School of Madrid, located in the campus of the Universidad Autónoma of Madrid, in Cantoblanco (Spain).

\section{General guidelines}

The children have played mostly by themselves, without adult interference, even though the two researchers were almost always present. One of the study's objectives was the observation of their learning behavior. In almost all cases the children started exploring the game by themselves without asking for help to the researchers. The Skylanders game itself has a tutorial which introduces the story that encompasses the adventures they will face throughout the game. The decision to make the study with boys and girls was taken to determine if boys are attracted to videogames more than girls as it is usually believed.

Skylanders allows two players to play simultaneously but it can also be played by a single player. We chose to always let them play in pairs to be able to observe their cooperation skills. We also decided to always make the number of participants (3 or 4 ) greater than the number of available controllers and action figures (2). This was done to create a situation in which some children could participate indirectly, without touching the controller, but nevertheless collaborating with the players. We also wanted the children to organize the game play sessions themselves while allowing everybody in the group to participate. Finally, we assumed that some conflicts would arise among the participants and we wanted to observe and determine the causes and the procedures to solve them in those cases.

\section{Design and data analysis}

A qualitative analysis was carried out on each individual session complementing with notes taken by the two observers. The material of all the sessions was analyzed for each individual hypothesis. 


\section{Results}

a. As expected, all the children showed a spontaneous interest to explore and participate in the game, even though it was completely unknown to many of them. Other had some information because of adverts and very few had specific and concrete knowledge. Boys and girls of the three age groups actively participated to learn how to play Skylanders. In reality, as the weeks passed, the interest that arose from the game outgrew the possibilities of participation. There were far more boys and girls who wanted to play than opportunities to do so. Therefore, during the last weeks, we organized a second team of players which played simultaneously with another game and in another screen while under supervision of an adult from our staff. Meanwhile, the "experimental" group was observed and recorded as they played. This situation, designed to avoid disappointing many kids who wanted to play, allowed us to observe a curious collaboration between teams, a loud exchange of information and tips from one team to the other. They spontaneously established the communication from one team to the other with questions like "Where are you?". This interest in knowing which exact part of the adventure was playing each team at the moment shows that even though they were using different consoles, they felt like they were exploring and traversing the same world.

b. The kids very actively participated in the collaborative creation of game meaning. Each player intensely explored the different elements of the game and shared them while discovering them. Most of them started by exploring the way the controllers worked, the possibilities of each action figure, the procedure to set them on the platform and "adopting" them, etc... They worked as a "team" without explicitly defining or organizing themselves as such. Some paid attention to the information that the game itself provided regarding the backstory of the Skylanders. Others explored the concrete actions of each action figure, the way the controllers worked, etc... Many split their attention between those aspects. But all share what they discover and give tips or explicit orders to their classmates regarding what has to be done to make progress. Nobody says it explicitly, but they all implicitly assume that in order to play together they have to cooperate. When one kid makes progress in the acquisition of skills it does not interfere with the progress of the others, on the contrary, it motivates them to improve their own skills. 
For example, in the adventure mode of Skylanders there are some puzzles which the players have to solve. All the groups solved them without any help from adults. But, when one of the puzzles proved too challenging, the group discussed the best way to tackle it and assessed the effectiveness of different solutions. It did not seem to be an individual task for a player's character but it was instead, a common problem to be faced together.

In fact, as the players progressed in their understanding of the game and the mastery of the necessary skills to play it, they shared their knowledge and skills with their classmates. Very often, it was the player who did not have the controller in hands who was able to perceive the possibilities or circumstances of the adventure that the other two (who had the controllers) did not yet see. This result demonstrates that Skylanders works as a game and that, as in every game, the fundamental thing is participating and collaborating with others. Many times, in the three age groups, the boys and girls would ask their friends to "go faster", "follow" or "jump" as if they were the character being manipulated onscreen.

c. In many occasions, when the task at hand proved too difficult for a player, they left the controller on their table and allowed a classmate to show them what had to be done to go faster, follow, jump, etc. These are clear examples of what Bruner (1984) called scaffolding which is related with what Vygotsky (1979) defined as the Zone of proximal development: the distance between what one can do alone and what one can do with the help of someone with better skills. The child who knows the most or understands the game at a faster rate, will offer that knowledge to those who are slower learners. Once a kid learns something new in the game that nobody else knows, like the way the controller works, the features of each action figure, the way to solve a puzzle, etc, he actively and explicitly teaches it to others. In many other cases, those who did not know something would ask questions directly to the knowledgeable player. This type of mutual teaching exponentially increases the learning speed of the entire group. This scaffolding, these actions of completing, supporting or explicitly teaching concrete actions to less competent players, make possible progressing in the game and that everyone can participate and feel like active members and leaders of a shared adventure.

d. Evidently, as in every game, this common goal, this necessity to collaborate to make the game possible, does not exclude the conflicts that may arise between players for 
their eagerness to be better than the others. But, because of the common interest or goal to keep on playing, the conflicts were quickly resolved every time by the players themselves. The researchers were needed in some cases to, as adults, impose the desired solution: giving the controller to another player to participate. Adult intervention usually consisted of commenting: "You are three (or four) players and there are only two controllers, only two can play at the same time. You have to get organized so that everybody can play". In many groups, especially in 4th and 6th grade, no such comment was necessary.

Worthy of mention is the surprising role of leadership showed by some players, specially by a 7 year old girl, who chose to give up her chance to play during the first minutes of the game and opted instead to act as an external tutor and advisor, giving very useful information to other players (boys or girls) and explicitly celebrating their progress. When she decided she wanted to play, the controllers were gladly offered to her. And, after playing for almost 15 minutes, she decided she had had enough and that it was time for the kid who had given her the controller to play again.

On the contrary, in many cases small arguments arose when some players who were merely watching, had to participate. In some of the 6th grade groups (11 and 12 years old) the time playing management was done by the players themselves with their own wristwatches. In many cases the conflict stemmed from the desire to retain the same character they had previously used, attributing their success to the character and not to the actions they had performed with it.

In the case of a 2 nd grade girl (7 years old) the conflict arose when she adamantly refused to let go of the action figure she held in hand with a tight grip for more than a minute, leading to protests and appeals for adults to intervene by the other three players. But, even in this case, the girl finally gave the action figure to whoever had the right to keep on playing. She then grabbed another one of the available figures that were on top of a table without being used by any other player.

There was never a time, during the 11 weeks of the study that the game had to be interrupted because of the impossibility to reach an agreement when a conflict arose. However, once the sessions ended there where usually complains from 
somebody that felt they had less time to play than the others. But it was more common for all to comment on how much they had enjoyed the experience and to thank the researchers for the opportunity given.

e. The boys and girls of 6th grade (11 and 12 years old) showed a great deal of autonomy when exploring the game, in the shared construction of game meaning, in the distribution of roles throughout the sessions as well as when resolving their conflicts. It is fit to describe their behavior as self sufficient and independent from the adults. The game world is theirs and they are the stars.

The 2nd grade players ( 7 and 8 years old) used to ask for permission to start the game, they would openly ask how the controllers worked and asked questions such as "¿can I do this?" as they were performing an action. When faced with a persistent roadblock (for example, when they tried to play but had in their hands the wrong controller; or when they tried to change the game mode or customize their characters, etc) they didn't hesitate in seeking the assistance of an adult.

The boys and girls from the 4th grade ( 9 and 10 years old) were far more independent than those in 2nd grade but, when they faced a persistent roadblock or some conflicts of interest, they had less resources to solve them than their classmates from 6th grade. These global differences between age groups do not interfere with the great differences that can be seen between individuals in skills, social abilities and independence from adults.

The cooperation among two players is more effective as their ages increase. When faced with conflicting opinions, the boys and girls from 6th grade (11 and 12 years old) managed to reach an agreement and continue playing the adventure. Those in 4th grade (9 and 10 years old) and especially those in 2 nd grade ( 7 and 8 years old) kept arguing even if that interfered with the game session. The most obvious case can be seen with the character's movement. If they tried to walk in opposite directions, while exploring the world in adventure mode, they reached a point in which neither of them could make further progress. And yet, they each persisted in those directions even if they were both paralyzed. The only solution is that one character follows the other. This type of interruption or disagreements between players is a lot more 
frequent in the 4th grade than in the 6th and even more in the 2nd grade than in the 4th.

f. All the players, boys and girls from the three age groups, truly enjoyed the game sessions. Most of them thanked us with great courtesy for the opportunity and asked when it would be possible to play Skylanders again.

Even though the boys and girls actively participated in the game and, as previously mentioned, with great satisfaction, we noticed some differences in their preferences which are worthy of mention. They all actively participated and collaborated with each other to make progress in the adventure mode. But most of the girls showed less interest in the battle mode. In some cases they immediately gave up the controllers to the males in the group. In other cases, when they had the controller again, they insisted on switching back to adventure mode. On the other hand, in all the age groups, there were males who actively participated in battle mode or who asked to switch back to that game mode while they were playing adventure mode with others.

g. Overall, the males were more interested in the action, or in discovering different strategies to achieve goals (for example, hoarding points, collecting treasures, finding keys to open doors, etc...). The girls were more interested in the context of those actions, the plot of the game and the personalities of the characters. And, in general, the girls liked the adventures in Skylanders more than the different battles.

Finally we must point out that even though some girls were better and faster than their male team mates in learning and practicing the game, most of them obeyed the boys and paid attention to their advice. It is highly likely that the extended belief that males are more skillful and competent is also present in the psyche of the girls even at such young ages as these.

\section{Discussion and conclusion}

\section{Inaccurate beliefs}

A very ingrained belief in adults, parents or teachers, is that only boys are interested in videogames and not girls, and that, if they are interested, the girls are slower at learning than 
the boys. Various studies have shown that both gender do play video games, although they have different preferences in the type of videogames as shown by Greenberg et al.(2010) among others. In our case from the first day of the study we discovered that this is a false belief. The girls enjoyed playing Skylanders as much as the boys and they learned to play it equally fast. This does not inhibit them, as previously mentioned, to being receptive to the advice of the boys of the same age.

\section{Self-regulation}

An important effect both games and videogames provide players with a lot of possibilities of self-regulation. Lacasa et al (2009) describes that this capacity of selfregulation among children of primary education. In our study, not having set the allotted time for each player to play, the players themselves determined when it was time to switch turns, who began, which game mode would be selected, etc... All the groups managed to selfregulate perfectly. Most players consented to take turns right after finishing a chapter. Others used subjective time as the criteria according to a previous arrangement. And, in the case of the 11 and 12 years old group, they also used time as the criteria but measuring it with their wristwatches.

\section{Role distribution}

Beck and Wade (2004) have demonstrated the collaboration between group of players and the acquisition of social skills while playing videogames. In our study, spontaneously all members of each group, after just a couple of minutes, started assuming different roles in the group. We have already commented on the role of the leader taken on by some boys and girls. They assume the responsibility of informing about the controller, the console, the features of the characters, the available actions, etc... They also point out the different directions in which the characters must move or their limitations (for example, the impossibility of jumping to outer space). Other players assume the role of a sort of advisor or substitute leader when he/she does not know what has to be done. Others, obviously, are very receptive and limit themselves to following instructions. The interesting thing is that this process is neither the consequence of any explicit agreement nor the result of a debate. It is a totally spontaneous and unconscious division of labor. 


\section{Boys and girls: Playing together but not mixed up}

In all of these groups there were boys and girls and they were thus designed to be able to observe the participation dynamics as related to the gender. We initially proposed groups of 3 ( 2 girls and a boy or vice versa). But right from the start, the team member who was alone regarding the gender, invited a friend of the same gender. This way, the teams reached a spontaneous balance from the initial asymmetrical design. We accepted this since it helped create a ludic environment which was the essential condition of the study. Therefore, in most of our observations we studied two boys or two girl players. In a certain way, the Skylanders sessions reproduced a behavior regularly seen during recess: even though they play the same game (hide and seek, cops and robbers, etc...) at these ages, they prefer to play with kids of the same gender, boys with boys and girls with girls.

\section{Age related differences in the learning process}

Everybody understands the basic controls of the game very quickly. However, the oldest (6th grade) develop much better advanced strategies in battles and discover more hidden elements in the game world.

\section{Some anecdotes and observations of particular interest}

Two 6th graders, who were excellent friends, participated in one of the first groups. One of them has attention deficit disorder, even in games. With extraordinary subtlety and affection, his friend managed to make him participate and enjoy the game, focusing his attention and constantly giving him suggestions. Meanwhile, despite his difficulties to focus his attention, this player made surprising questions: How does the physical object enter the virtual world onscreen? or what was the objective of all the notes we, the researchers, were taking. Or the reason why only two players could play at the same time when he would have liked for them to play three at the same time. The answer to "no more than two action figures can be placed on the platform" did not convince him and he asked again Why? Why is it not possible?

\section{The virtual world as real and the real world as virtual}

In some cases the players, boys and girls, immerse themselves so deeply in the story that they start talking with the characters represented by the action figures. And when one of these characters says thanks, they reply: You're welcome! They treat the action figure as if it were a real human being. 
The opposite occurs when they attribute to the specific properties of an action figure, the success of the actions they have performed with it. For example, in battle mode, if they managed to beat the opponent, they attribute the success to the abilities of the characters and not to their skills with the controller. And immediately the other player, the loser, wants to use the character that has won. All the decisions they have taken, the movements and actions performed, are attributed to the character as if it was a living and independent entity. Explaining why there was so much interest in using the character with which a player managed to make progress in the adventure or win the battles.

We have already mentioned the case of a 7 year old player who tried to prevent others from using her character. She grabbed the Eruptor, action figure with which she had won many battles, and held it tight in her hand to prevent other players from using it. As closing thought, we can confirm that Skylanders is a good game which, as all the good toys, stimulates the children to immerse themselves in the game world and cooperate and compete with other children. Boys and girls enjoy it in equal measure. They learn to manage their resources and navigate Skylanders very quickly in its different game modes and they rapidly collaborate to construct the game meaning and determine what has to be done and how to do it. They share with curiosity and efficacy the information and skills they acquire and help their classmates to be more competent players. They seek and use the help of adults to achieve their objectives but without giving up the importance of their own learning while they have fun doing it. And, without doubt, it is a game that allows them to socialize and do things together. An excellent counter example of the supposed "isolation" that videogames produce.

It would be helpful to complement this first study, with a small number of subjects in a school from Madrid, with a more extensive one which would help us verify our initial findings. It would also be interesting to explore the learning process of the game with boys and girls of younger and older age groups than the ones studied in this research. 


\section{References}

Bavelier, D. (2003). Action video game modifies visual selective attention. Nature. $423,534-537$.

Beck, J. Wade, M. (2004) Got Game: how the gamer generation is reshaping business for ever. Harvard Business School Press, Cambridge, MA

Bogost. (2010) Persuasive Games: the expressive power of videogames. The MIT Press.

Bruner, J. S. (1972a). Concepciones de la infancia: Freud, Piaget y Vygotsky. En J. Linaza (comp.) Acción, pensamiento y lenguaje: Escritos de J. S. Bruner, (p. 31-44). Madrid: Alianza (1984).

Bruner, J. S. (1972b). Immaturity: its nature and uses. American Psychologist 27, 687-708.

Bruner, J.S. (2012). What Psychology Should Study. International Journal of Educational Psychology, 1(1), 5-13.

Ferguson, C. J. (2010) Blazing angels or resident evil? Can violent video games be a force for good? Review of General Psychology, 14(2), pp. 68-81.

Gee, J.P. (2005) "Demonstrating the important Learning Found in COTS Games", Paper presented at The Serious Game Summit. San Francisco, California.

Ferguson, C. y Rueda, S. (2010). The Hitman, Violent Video Game Exposure Effects on Aggressive Behavior, Hostile Feelings, and Depression Study. European Psychologiste, 15, 99-108.

González, J. (2010) Jugabilidad. Caracterización de la experiencia del jugador en videojuegos. Tesis Doctoral. Universidad de Granada. Available on the Dialnet database. (2010)

González, C., Toledo, P., González, J., Collazos, C. García, C., Hernández Bieliukas, Y. (2013). Diseño de juegos serio s colaborativos para niños hospitalizados. Venezuela. Tecnologías y aprendizaje.

Avalaible on http://ccita2013.utcancun.edu.mx/descargas/LibroUT, Vol2.pdf González-González, C. \& Blanco-Izquierdo, F. (2012). Designing social videogames for educational uses. Computer Education , 58 (1), 250-262.

Guerrero, J. (2014). Herramientas lúdicas, pedagógicas y metodológicas a través de los videojuegos. Bogotá. Revista e-ikon 
Lacasa, P., Méndez, L., \& Martinez, R. (2009). Using videogames as educational tools: Building bridges between commercial and serious games. In Marja Kankaanrata \& Pekka Neittaanmäki (eds.). Parte II Learning (69-82). Milton Keynes, UK: Springer Verlag

Lacasa, P., Méndez, L., \& Martinez, R. (2008). Bringing commercial games into the classroom. Computers and Composition, 25, 341-358.

Linaza, J.L. y Bruner, J.S. (2012). La importancia del contexto cultural en el desarrollo del juego infantil. En J.A. García Madruga, R. Kohen, C. del Barrio, I. Enesco y J.Linaza (Editores), Construyendo Mentes. Ensayos en homenaje a Juan Delval, Constructing Minds. Essays in honor of Juan Delval (p. 245-269). Madrid: UNED.

McGonigal, J. (2011). Reality is broken: Why games make us better and how they can change the world.Penguin.

Mainer, B. (2006). El Videojuego como material educativo: La Odisea. Icono 14. Revista de Comunicación y Nuevas Tecnologías, 7, 1-28.

Padilla-Zea, N. (2011) Metodología para el diseño de videojuegos educativos sobre una arquitectura para el análisis del aprendizaje colaborativo. Tesis doctoral. Universidad de Granada. Available on the Dialnet Database.

Padilla Zea, N. (2014). El uso educativo de los videojuegos http://www.juntadeandalucia.es/educacion/webportal/descargas/familiaslectoras/flash/coleccion/resources/cariboost_files/cuaderno09.pdf

Vygotsky, L. S. (1979). Consciousness as a problem in the psychology of behavior. Soviet psychology, 17(4), 3-35. 
Zhuxuan Zhao et al.

[This page intentionally left blank] 